\title{
ASSESMENT TINGKAT KEPUASAN DOSEN DENGAN METODE SERVQUEL PADA UNIVERSITAS XYZ
}

\author{
Hana Catur Wahyuni, Wiwik Sumarmi \\ Prodi Teknik Industri, Fakultas Teknik \\ Universitas Muhammadiyah Sidoarjo \\ hanacatur@umsida.ac.id
}

\begin{abstract}
ABSTRAK
Perguruan tinggi (PT) mempunyai peran penting dalam mengembangkan kehidupan masyarakat Indonesia. Dosen merupakan unsur dalam PT diharapkan dapat mempunyai kinerja yang baik sehingga dapat meningkatkan image masyarakat terhadap PT tersebut. Salah satu usaha untuk meningkatkan kinerja dosen adalah dengan memberikan kualitas layanan yang baik. Penelitian ini bertujuan untuk mengetahui dan menentukan jenis atribut kualitas layanan yang perlu diperbaiki. Teknik pengambilan data dilakukan melalui penyebaran kuisioner berdasarkan dimensi Servquel (tangible, reliability, responsibility, assuarance, empathy) Responden yang digunakan adalah dosen pada Universitas XYZ sebanyak 87 orang. Hasil penelitian menunjukkan bahwa kualitas layanan yang ada saat ini belum memenuhi harapan dosen, dan jenis atribut yang perlu dipebaiki adalah kebersihan kamar mandi (T6), kerapian ruang kuliah (T3), Ketersediaan informasi yang terkait dengan pengembangan dosen (informasi tentang jadwal penelitian, kepangkatan dll) (A17).
\end{abstract}

Kata Kunci: Servquel, tangible, reliability, responsibility, assuarance, empathy.

\section{PENDAHULUAN}

Perguruan tinggi (PT) merupakan unsur penting dalam meningkatkan kualitas kehidupan masyarakat di Indonesia. Hal ini disebabkan PT merupakan sumber penemuan berbagai macam teknologi yang dapat dimanfaatkan oleh masyarakat. Taylor (Semiawan dalam Srinadi dkk, 2008) menyatakan bahwa peningkatan mutu PT didasarkan pada empat pilar pokok sumber daya yaitu: sumber daya fisik, keuangan, informasi, dan sumber daya manusia.

Dosen, sebagai salah satu bentuk sumber daya manusia mempunyai peran penting dalam pengembangan PT. Menurut Undang- undang no 14 tahun 2005 tentang guru dan dosen, menyebutkan bahwa dosen adalah pendidik profesional dan ilmuwan dengan tugas utama mentransformasikan, mengembangkan dan menyebarluaskan ilmu pengetahuan, teknologi dan seni melalui pendidikan, penelitian dan pengabdian masyarakat. Dosen yang mempunyai kinerja baik akan mampu menghasilkan lulusan yang berkualitas sehingga akan meningkatkan daya saing PT. Hal tersebut pada akhirnya akan menciptakan image yang baik pada PT tersebut.

Oleh karena itu, perlu diciptakan suasana yang mampu meningkatkan kinerja dosen. Salah satu hal yang mempengaruhi kinerja dosen adalah tingkat kepuasan dosen melalui faktor hasil kerja yang sesuai dengan keinginan institusi, kesesuaian antara tuntutan pribadi dengan tugas, informasi yang jelas tentang hasil kerja, dan ketrampilan (Sadira, 2009). Selain itu, tingkat kepuasan dosen pada PT perlu digali sebagai bahan evaluasi bagi pihak manajemen dalam merumuskan berbagai kebijakan yang terkait dengan dosen.

Universitas XYZ merupakan salah satu PT yang sedang berkembang dan berada di wilayah Propinsi Jawa Timur. Kepuasan dosen menjadi faktor penting pada Univ XYZ, karena pihak manajemen berharap bahwa dengan dosen yang puas terhadap kondisi Univ XYZ, maka kinerja dosen dapat meningkat sehingga proses transfer ilmu dapat berjalan dengan baik. Dengan adanya kondisi tersebut, pada akhirnya dapat meningkatkan kualitas lulusan yang dihasilkan Universitas XYZ. Oleh karena itu, secara periodik Universitas XYZ selalu melakukan pengkajian terhadap tingkat kepuasan agar diketahui sejauh mana dosen telah puas, dan hal- hal apa saja yang perlu diperbaiki. 
Universitas XYZ merupakan salah satu bentuk industri jasa. Pada dasarnya, ukuran kualitas pada industri jasa berbeda dengan kualitas pada industri manufaktur. Tjiptono (2005) mengungkapkan bahwa jasa mempunyai empat karakteristik utama yang membedakan dengan barang, yaitu:

1. Intangibility.

Jasa merupakan sesuatu yang tidak dapat disentuh dan tidak dapat dirasa serta tidak dapat dengan mudah didefinisikan, diformulasikan, atau dipahami secara rohaniah. Lebih dari itu, jasa merupakan sesuatu yang hanya dapat dikonsumsi tetapi tidak dapat dimiliki.

2. Inserability.

Kunci keberhasilan bisnis jasa terdapat pada proses rekrutmen, kompensasi, pelatihan dan pengembangan karyawan.

3. Variability.

Jasa termasuk dalam non standardized output, yang berarti banyak variasi bentuk, kualitas dan jenis, tergantung pada siapa, kapan dan dimana jasa dihasilkan.

4. Perisability

Jasa merupakan komoditas yang tidak tahan lama dan tidak dapat disimpan. Permintaan jasa yang fluktuatif maka beberapa permasalahan akan muncul terutama berkaitan dengan kapasitas menganggur, pelanggan yang tidak terlayani sehingga beralih ke penyedia jasa yang lain.

Salah satu metode yang dapat digunakan untuk mengetahui tingkat kepuasan pada industri jasa adalah metode Servquel. Dengan skala Servquel untuk mengevaluasi kualitas jasa/pelayanan, dilakukan dengan membandingkan antara pelayanan yang di harapkan dengan persepsi atas pelayanan yang diterima (Gap análisis) (Dharmayanti, 2006).

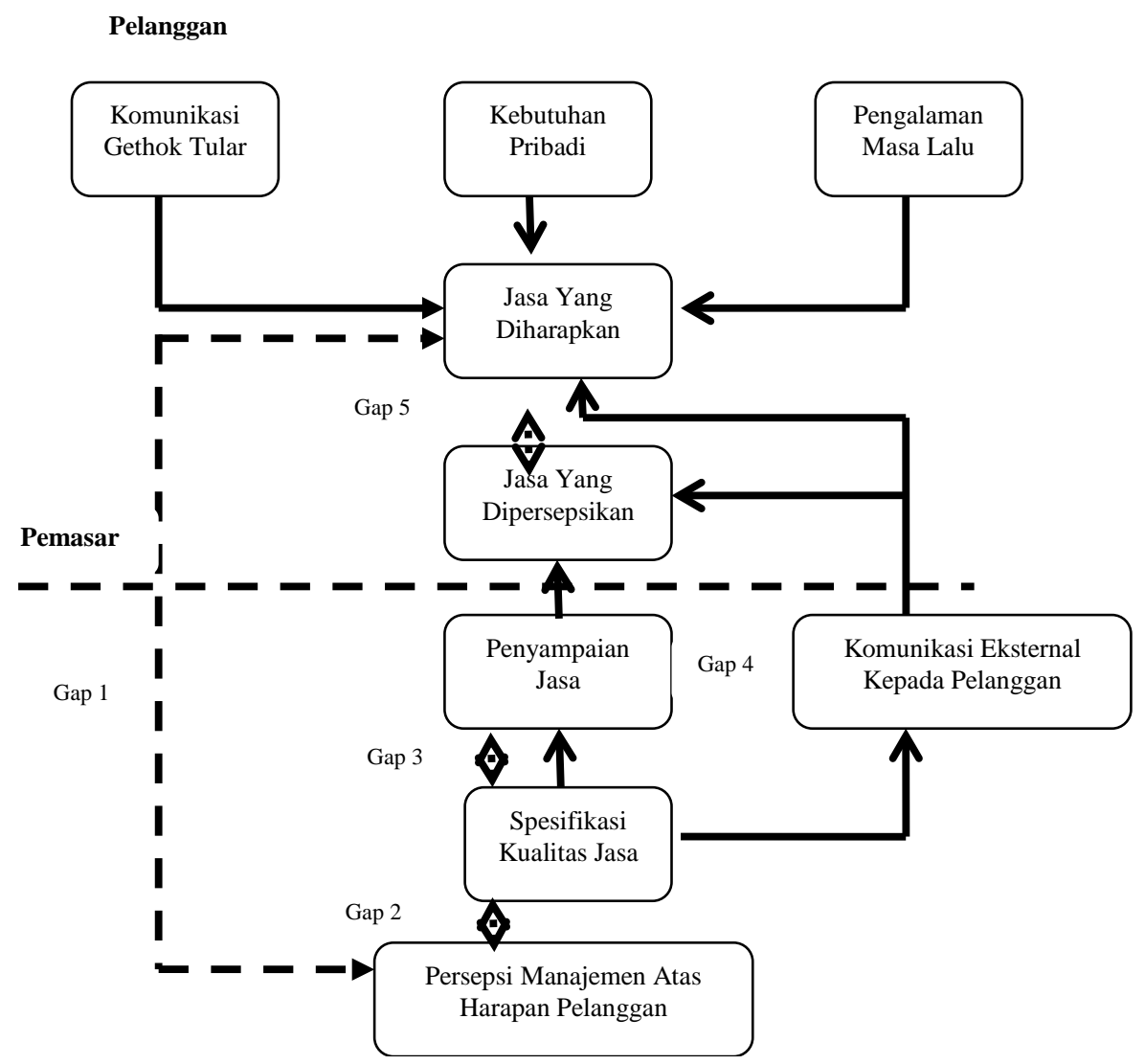

Gambar 1. Konsep Servquel

Sumber: Parasuraman dalam Tjiptono, 2011 
Metode Servquel dikembangkan oleh A Parasuraman, Valerie A Zeithaml, Leonard L. Berry dengan ditemukannya lima gap yang seringkali menjadi sumber permasalahan pada peningkatan kualitas jasa, yaitu (1) gap antara harapan pelanggan dan persepsi manajemen, (2) gap antara persepsi manajemen terhadap konsumen dan spesifikasi kualitas jasa, (3) gap antara spesifikasi kualitas jasa dan penyampaian jasa, (4) gap antara penyampaian jasa dan komunikasi eksternal, (5) gap antara jasa yang dipersepsikan dan jasa yang diharapkan (Tjiptono dkk, 2011).

Dengan melakukan pengukuran tingkat kepuasan konsumen melalui metode Servquel, maka akan dapat dirumuskan berbagai langkah perbaikan untuk meningkatkan kualitas layanan.

\section{METODE PENELITIAN}

Tahapan yang digunakan dalam penelitian adalah sebagai berikut:

1. Tahap pengumpulan data.

a. Pengumpulan data dilakukan melalui penyebaran kuisioner pada responden penelitian. Dimana, responden penelitian adalah dosen tetap Universitas XYZ. Atribut kuisioner terdiri dari dimensi servquel, yaitu: tangible, responsiveness, reliable, assurance, dan empathy. Kuesioner terbagi menjadi dua bagian pertanyaan, bagian pertama berisi tentang data diri responden, bagian kedua berisi tentang tingkat kepuasan. Pengukurannya menggunakan skala likert yang terdiri dari empat poin, dimulai poin 1 sangat tidak puas sampai poin 4 sangat puas.

b. Wawancara

Wawancara dilakukan kepada pihak-pihak yang mengerti tentang sistem layanan yang ada. Wawancara dilakukan untuk mengerti dan mengetahui kondisi existing perusahaan.

2. Tahap pengolahan data

a. Menghitung nilai gap yang terjadi. Nilai gap ini berasal dari nilai harapan dosen dan persepsi dosen terhadap kualitas layanan yang diberikan. Jika gap bernilai positif maka dosen puas atas layanan yang diterima, karena apa yang mereka persepsikan atas layanan yang diterima melebihi harapan atas layanan yang akan diterima. Jika gap bernilai negatif, maka dosen tidak puas karena harapan atas layanan yang akan diterimanya lebih tinggi dari apa yang dosen persepsikan atas layanan yang diterimanya. Jika gap sama dengan nol, maka tidak ada gap, karena kualitas layanan yang diterima dosen sama dengan yang diharapkan.

b. Mengidentifikasi atribut-atribut yang mempunyai nilai gap tertinggi. Nilai tersebut mengindikasikan bahwa atribut harus segera di perbaiki jika ingin meningkatkan kepuasan dosen.

\section{HASIL DAN PEMBAHASAN}

Atribut yang digunakan dalam penelitian adalah didasarkan pada teori service quality (servqual) yang terdiri dari lima dimensi, yaitu:

1. Reliabilitas (reliability), berkaitan dengan kemampuan pihak universitas untuk memberikan layanan yang akurat sejak pertama kali tanpa membuat kesalahan apapun dan menyampaikan jasanya sesuai dengan waktu yang disepakati.

2. Daya tanggap (responsiveness), berkenaan dengan kesediaan dan kemampuan para karyawan untuk membantu para dosen dan merespon permintaan mereka, serta menginformasikan kapan jasa akan diberikan dan kemudian memberikan jasa secara cepat.

3. Jaminan (assurance), yakni perilaku para karyawan mampu menumbuhkan kepercayaan pelanggan terhadap universitas, dan bisa menciptakan rasa aman bagi para dosennya. Jaminan juga berarti bahwa karyawan selalu bersikap sopan dan menguasai pengetahuan dan ketrampilan yang dibutuhkan untuk menangani setiap pertanyaan atau masalah dosen. 
4. Empati (empathy), berarti pihak universitas memahami masalah para dosen dan bertindak demi kepentingan dosen, serta memberikan perhatian personal kepada dosen dan memiliki jam operasi yang nyaman.

5. Bukti fisik (tangibles), berkenaan dengan daya tarik fasilitas, perlengkapan, dan materialyan digunakan pihak universitas, serta penampilan karyawan.

Kuisioner evaluasi kepuasan dosen disebarkan kepada dosen dilingkungan Universitas XYZ dengan jumlah responden sebesar 87 responden. Atribut yang digunakan dalam kuisioner adalah sebagai berikut:

Tabel 1. Atribut Evaluasi Kepuasan Dosen

\begin{tabular}{|c|c|}
\hline Dimensi & Atribut \\
\hline \multirow{7}{*}{$\begin{array}{l}\text { Tangible (Bentuk } \\
\text { fisik) }\end{array}$} & Kebersihan dan kenyamanan ruang kuliah (T1) \\
\hline & Kebersihan dan kenyamanan ruang dosen (T2) \\
\hline & Kerapian ruang kuliah (T3) \\
\hline & Kerapian ruang dosen (T4) \\
\hline & $\begin{array}{l}\text { Ketersediaan peralatan mengajar di ruang kuliah (LCD, Papan tulis dll) } \\
\text { (T5) }\end{array}$ \\
\hline & Kebersihan kamar mandi (T6) \\
\hline & Kerapian petugas administrasi (T7) \\
\hline \multirow[t]{3}{*}{$\begin{array}{l}\text { Reliability } \\
\text { (Keandalan) }\end{array}$} & $\begin{array}{l}\text { Perkuliahan dimulai dan diakhiri sesuai dengan waktu yang dijadwalkan } \\
\text { (Rl8) }\end{array}$ \\
\hline & $\begin{array}{l}\text { Urusan administrasi dapat diselesaikan sesuai waktu yang dijanjikan } \\
\text { oleh petugas (Rl9) }\end{array}$ \\
\hline & $\begin{array}{l}\text { Informasi yang diberikan petugas terhadap suatu prosedur mudah } \\
\text { dimengerti (Rl10) }\end{array}$ \\
\hline \multirow{3}{*}{$\begin{array}{l}\text { Responsiveness } \\
\text { (Daya tanggap) }\end{array}$} & Petugas cepat memberikan respon terhadap keluhan dosen (Rp 11) \\
\hline & Keluhan dosen segera diselesaikan oleh petugas (Rp 12) \\
\hline & Petugas dapat diandalkan saat dibutuhkan. $\quad$ (Rp 13) \\
\hline \multirow{4}{*}{$\begin{array}{l}\text { Assurance } \\
\text { (Jaminan) }\end{array}$} & Keamanan parkir (A14) \\
\hline & Keamanan ruang kelas (A15) \\
\hline & Keamanan ruang dosen (A16) \\
\hline & $\begin{array}{l}\text { Ketersediaan informasi yang terkait dengan pengembangan dosen } \\
\text { (informasi tentang jadwal penelitian, kepangkatan dll) (A17) }\end{array}$ \\
\hline \multirow[t]{3}{*}{ Emphaty (Empati) } & Petugas memberikan perhatian terhadap kepentingan dosen (E18) \\
\hline & Petugas bersedia membantu persoalan yang sedang dihadapi dosen (E19) \\
\hline & $\begin{array}{l}\text { Petugas melayani dosen dengan kata-kata, perilaku yang baik dan sopan } \\
\text { (E20). }\end{array}$ \\
\hline
\end{tabular}

Penentuan jumlah sampel penelitian dilakukan dengan menggunakan persamaan Bernoulli dengan ketentuan sebagai berikut:

a. Tingkat kepercayaan yang digunakan : 95\%

b. Tingkat ketelitian

c. Jumlah kuisioner yang disebar

$: 10 \%$

d. Jumlah proporsi sample yang sah

e. Jumlah proporsi sample yang tidak sah

$: 87 / 90=0,96$

$: 3 / 90=0,04$

Sehingga jumlah sampel minimal yang butuhkan adalah:

$$
\begin{gathered}
n \geq \frac{\left(Z_{\alpha / 2}\right)^{2} \cdot p \cdot q}{e^{2}} \\
\mathrm{~N} \geq 59
\end{gathered}
$$


Karena jumlah responden penelitian lebih besar dari jumlah yang responden yang dibutuhkan berdasarkan persamaan Bernoulli (87> 59) maka sampel telah mencukupi untuk dilakukan pengolahan data.

\section{A. Profil Responden}

Profil responden berdasarkan jenis kelamin adalah sebagai berikut:

\section{Profil Responden Berdasarkan Jenis Kelamin}

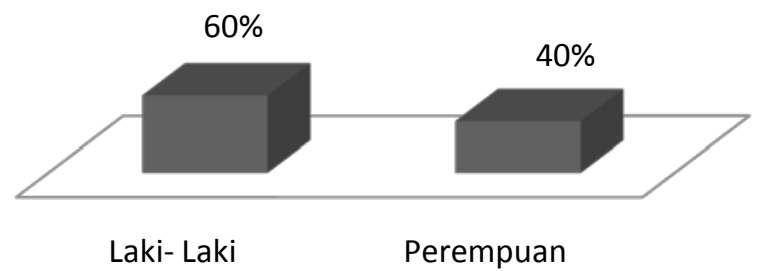

Gambar 1. Profil responden berdasarkan jenis kelamin

Profil responden berdasarkan jabatan akademik adalah sebagai berikut:

\section{Profil Responden Berdasarkan Jabatan Akademik}

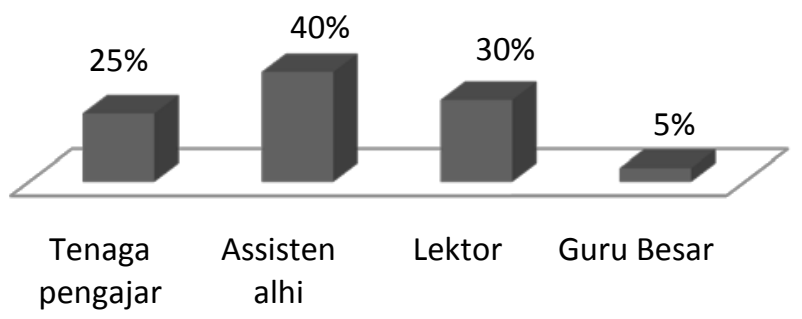

2. Profil responden berdasarkan jabatan akademik

Gambar

Selanjutnya, dilakukan uji Validitas dan reliabilitas. Pengujian validitas ini untuk mengetahui apakah kuisioner yang digunakan benar benar dapat digunakan untuk mengetahui apa yang ingin di ukur. Taraf signifikansi yang digunakan adalah $5 \%$. Sedangkan uji reliabilitas ini digunakan untuk melihat sejauh mana suatu hasil pengukuran itu relative konsisten. Dinyatakan reliable jika nilai alpha cronbach lebih besar dari 0,5 . Uji validitas dan reliabilitas dilakukan dengan menggunakan software SPSS 16. Hasil uji validitas dan reliabilitas menunjukkan bahwa semua instrumen dalam kuisioner adalah valid dan reliabel.

Langkah berikutnya adalah melakukan perhitungan nilai gap Servquel. Nilai gap diperoleh dengan mencari selisih antara harapan dosen dengan persepsi kualitas layanan yang diterima dosen saat ini. Skala harapan dosen diasumsikan 4 untuk semua atribut penelitian, hal ini didasarkan pada standar mutu pelayanan Universitas XYZ. Hasil perhitungan gap adalah sebagai berikut: 
Tabel 2. Perhitungan Nilai Gap.

\begin{tabular}{|l|l|l|l|}
\hline Atribut & Rata- rata persepsi dosen & Harapan dosen & Nilai gap \\
\hline T1 & 2,57 & 4 & 1,43 \\
\hline T2 & 2,75 & 4 & 1,25 \\
\hline T3 & 2,45 & 4 & $1,55^{*}$ \\
\hline T4 & 2,76 & 4 & 1,24 \\
\hline T5 & 2,62 & 4 & 1,38 \\
\hline T6 & 2,33 & 4 & $1,67^{*}$ \\
\hline T7 & 2,92 & 4 & 1,08 \\
\hline Rl8 & 2,99 & 4 & 1,01 \\
\hline R19 & 2,80 & 4 & 1,2 \\
\hline Rl10 & 2,84 & 4 & 1,16 \\
\hline Rp11 & 2,68 & 4 & 1,32 \\
\hline Rp12 & 2,62 & 4 & 1,38 \\
\hline Rp13 & 2,70 & 4 & 1,30 \\
\hline A14 & 2,92 & 4 & 1,08 \\
\hline A15 & 2,79 & 4 & 1,21 \\
\hline A16 & 2,84 & 4 & 1,16 \\
\hline A17 & 2,51 & 4 & $1,49^{*}$ \\
\hline E18 & 2,61 & 4 & 1,39 \\
\hline E19 & 2,76 & 4 & 1,24 \\
\hline E20 & 2,94 & 4 & 1,08 \\
\hline Rata- rata & 2,72 & & \\
\hline
\end{tabular}

Berdasarkan tabel 2 diketahui bahwa 3 atribut dengan nilai gap tertinggi sebagaimana dalam gambar berikut ini:

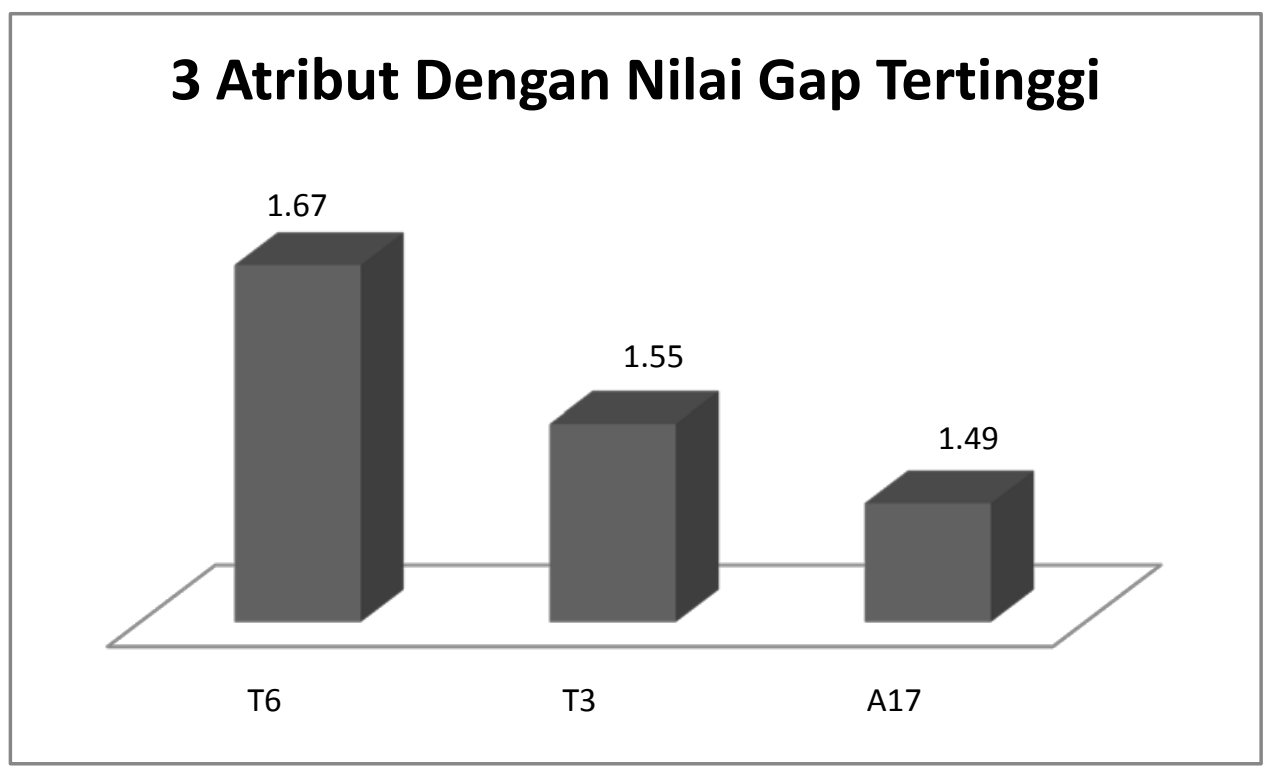

Gambar 3. Atribut dengan nilai gap tertinggi

Gambar 3 tersebut mencerminkan bahwa prioritas perbaikan harus dilakukan pada ketiga atribut tersebut, yaitu: kebersihan kamar mandi (T6), kerapian ruang kuliah (T3), Ketersediaan informasi yang terkait dengan pengembangan dosen (informasi tentang jadwal penelitian, kepangkatan dll) (A17). 


\section{B. PEMBAHASAN}

Hasil penelitian terkait dengan profil responden menunjukkan bahwa $60 \%$ berjenis kelamin laki- laki, sedangkan $40 \%$ berjenis kelamin perempuan. Sedangkan dari sisi jabatan akademik dosen, menunjukkan bahwa responden terbesar adalah responden dengan jabatan akademik assisten ahli. Kondisi ini merupakan suatu kondisi yang mengindikasikan bahwa perlu dilakukan berbagai kegiatan untuk meningkatkan jabatan akademik dosen yang lebih tinggi. Berdasarkan uji kecukupan data diperoleh hasil bahwa data yang diperoleh pada saat pengumpulan data dapat digunakan ke pengolahan data tahap selanjutnya.

Atribut pengukuran kepuasan dosen didasarkan pada dimensi Servquel yang terdiri dari tangible, reliability, responsibilty, assurance dan emphaty. Secara keseluruhan, rata- rata tingkat kepuasan dosen berada pada skala 2,72. Nilai tersebut menunjukkan bahwa tingkat kepuasan dosen berada pada kondisi kurang puas dengan apa yang diterima saat ini. Hasil pengukuran gap menunjukkan bahwa terdapat 3 atribut yang bernilai tinggi yaitu:

1. Kebersihan kamar mandi (T6).

2. Kerapian ruang kuliah (T3).

3. Ketersediaan informasi yang terkait dengan pengembangan dosen (informasi tentang jadwal penelitian, kepangkatan dll) (A17).

Hasil penelitian tersebut memperlihatkan bahwa pihak manajemen universitas harus memprioritaskan perbaikan pada kebersihan kamar mandi, kerapaian ruang kuliah dan ketersediaan informasi jika ingin tingkat kepuasan dosen meningkat. Hal tersebut senada dengan hasil penelitian Yousapronpaiboon (2014) yang mengemukakan bahwa kualitas layanan pendidikan tinggi di Thailand tidak memenuhi harapan mahasiswa. Analisis kesenjangan pada penelitian tersebut menunjukkan bahwa semua skor untuk nilai persepsi lebih rendah dari harapan sehingga pihak universitas melakukan berbagai upaya untuk meningkatkan kualitas layanan. Dari sisi atribut yang perlu diprioritaskan untuk diperbaiki, hasil penelitian sesuai dengan penelitian Wiyogo (2013) yang mengemukakan bahwa atribut Servquel yang perlu dilakukan perbaikan dalam rangka meningkatkan kepuasan konsumen adalah memperbaiki toilet yang rusak, menggunakan jasa cleaning service dan menggunakan jasa cleaning service untuk perawatan gedung/ ruang.

\section{KESIMPULAN}

Dari hasil pengolahan dan analisis data, maka kesimpulan yang dapat ditarik dari penelitian ini adalah:

1. Tingkat persepsi kualitas layanan lebih rendah jika dibandingkan dengan harapan dosen terhadap kualitas layanan universitas XYZ.

2. Rata- rata nilai kepuasan dosen adalah 2,72, yang menunjukkan bahwa dosen kurang puas dengan kualitas layanan yang diterima saat ini.

3. Prioritas perbaikan perlu dilakukan pada atribut: kebersihan kamar mandi (T6), kerapian ruang kuliah (T3), Ketersediaan informasi yang terkait dengan pengembangan dosen (informasi tentang jadwal penelitian, kepangkatan dll) (A17).

\section{DAFTAR PUSTAKA}

[1] Dharmayanti, 2006, Analisis Dampak Service Performance dan Kepuasan Sebagai Moderating Variabel Terhadap Loyalitas Nasabah (Studi Pada Tabungan Bank Mandiri Cabang Surabaya), Jurnal Manajemen Pemasaran, Vol 1 No 1, April.

[2] Sadira A, 2009, Penaruh Komitmen Keorganisasian dan Kepuasan Kerja Terhadap Kinerja Tenaga Edukatif/ Dosen (Studi di Universitas Brawijaya Malang), Jurnal Aplikasi Manajemen, Vol 7 No 1, Februari. 
[3] Srinadi Made , Nilakusmawati, 2008, Faktor- Faktor Penentu Kepuasan Mahasiswa Terhadap Pelayanan Fakultas Sebagai Lembaga Pendidikan (Studi Kasus FMIPA, Univ Udayana), Cakrawala Pendidikan, Nopember, XXVII No 3.

[4] Tjiptono, 2005, Total Quality Service, PT ANDI, Yogyakarta

[5] Tjiptono F, Candra G, 2011, Service, Quality \& Satisfaction, Penerbit ANDI, Yogyakarta.

[6] Yousapronpaiboon K, 2014, Servquel: Measuring Higher Education Service Quality In Thailand, Procedia, Social- Behavioral Sciences 116, pp 1088-1095.

[7] Wiyogo, Surachman, Rudy Soenoko, Nasir Widha Setyanto, 2013, Intergrasi Servquel dan Quality Function Deployment Untuk Pengukuran Kualitas Layanan, Jemis, Vol 1 No 1. 